Peer-Reviewed Article

ISSN: 2162-3104 Print/ ISSN: 2166-3750 Online Volume 7, Issue 3 (2017), pp. 499-521

(C) Journal of International Students http://jistudents.org/ doi: 10.5281/zenodo.569941

\title{
International Students from Melbourne Describing Their Cross-Cultural Transitions Experiences: Culture Shock, Social Interaction, and Friendship Development
}

\author{
Nish Belford \\ Monash University, Australia
}

\begin{abstract}
Drawing from a study that explored how international students experience cross-cultural transitions after living and studying in Melbourne for a few years, this paper, in particular, examines the participants' experiences with culture shock, social interaction, and friendship development. The findings include narratives of their personal stories and perspectives on social engagement and friendship ties with a particular focus on variables including cultural similarity, intercultural communication competence, intercultural friendship, and relational identity to influence their experiences.
\end{abstract}

Keywords: cross-cultural transition experiences; culture shock; friendship development; international students; social interaction.

Within the market-driven landscape of international education (Pham \& Saltmarsh, 2013), international students reside "at the center of a complex network of international academic relationships" (Altback, 1991, p. 305) in a worldwide trend towards the internationalization of knowledge and research. Australia is one of the most popular destinations for International students from the Indian Ocean, and the Asia Pacific regions to pursue tertiary education. International students make a significant contribution to Australian society, diversifying and enriching communities, and strengthening Australia's global networks (Australian Bureau of Statistics, 2012). There are several benefits offered to international students in Australia giving them access to gain high quality internationally recognized 
education and opportunities for work experience. The International education sector brings a huge contribution to the Australian economy and it adds to the cultural diversity of the society.

Melbourne is a cosmopolitan and diverse global city that attracts many international students (Mansouri, 2009) and the influx of international students is estimated to increase in the future (Australian Education International, 2012; Edwards, 2011). In 2012, there were 148,860 international students registered in Victoria and in 2015 the numbers have increased to 194,870 (Australian Education International, 2012; Department of Education and training, 2016). The international education industry has a significant contribution to Melbourne's knowledge sector in boosting "as an international center of excellence for tertiary education" (City of Melbourne, 2013, p. 9).

Academic mobility in higher education opens multiple horizons for many students to study overseas away from their home country. As international students discover the multiplicity of prospects and overture of educational experiences in a new country, they also undergo challenges to adapt and adjust in a host environment. Australia plays a significant role in international education and there is a pressing need to further understand how international students cope with cross-cultural transitions in view to provide them with better support systems through their social and learning experiences in this country. It is equally important to extend scholarly knowledge on how international students develop patterns of social interaction and friendship that contribute to their overall well-being within their adjustment process. So far, there has been less emphasis on reports and strategic plans on international education in Australia which suggests how to facilitate and support international students through their educational and social experiences (Marginson, 2011; Murray, Hall, Leask, Marginson, \& Ziguras, 2011)

This paper investigates the personal perspectives of a group of international students in Melbourne on 'culture shock', social interaction and friendship development. The findings add to scholarly knowledge and the current understanding of cross-cultural transition experiences of international students' social adaptation and adjustment in a host culture.

\section{LITERATURE REVIEW}

\section{Cross-cultural Transition Experiences}

A number of studies have explored international students' experiences with cross-cultural transition, adaptation and acculturation processes, and intercultural adjustments (e.g., Altback, 1991; Bista \& Foster, 2016; Brown \& Brown, 2013; East, 2001; Gareis, 2012; Gill, 2007; Gu, Schweisfurth, \& Day, 2010; Hotta \& Ting-Toomey, 2013; Zhou, Jindal- 
Snape, Topping, \& Todman, 2008). Cross-cultural transition is distressing and international students equally experience culture shock (Zhou et al., 2008). This term was first conceptualized by Oberg, (1960); being a form of disorientation when an individual transits through an unfamiliar culture, while away from their close family and friends. A sudden loss of familiar cultural norms and familial support often make international students more vulnerable to experiencing 'culture shock' (Pyvis \& Chapman, 2005). Theories applied to the study of international students and their experience with 'culture shock' has been criticized for its clinical orientations on early models of typology (Hwang, Martirosyan, \& Moore, 2016); however different views recently emerged (Zhou et al., 2008).

Zhou et al. (2008) discuss 'cultural learning', stress coping models and social identification theories (Furnham \& Bochner, 1986) as more contemporary and comprehensive in understanding 'culture shock' when people are exposed to a new culture. These theories together with the different components of response such as affect, behavior and cognition (ABC) describe the different aspects of changes that arise from intercultural contact (Hwang et al., 2016; Zhou et al., 2008). In these three theories, the concept of 'culture shock' has been transformed into "contact- induced stress" accompanied by social skills deficits to deal with cultural conflicts and life changes (Hwang et al., 2016; Zhou et al., 2008, p. 65). New terms such as adaptation and acculturation models (Ward, Bochner, \& Furnham, 2005) are discussed in research literature which refers to other ways of managing and improving social skills (Zhou et al., 2008). An individual keen to adapt and acculturate in a new culture needs coping strategies and a more active than passive effort in acquiring new social skills. These theories provide a more comprehensive model of understanding cultural adaptation and acculturation of international students (Zhou et al., 2008) with more opportunities for personal growth, development and 'cultural learning' (Hwang et al., 2016; Kim, 2001; Ward et al., 2005)

The process of adaptation and adjustment in a host country is challenging and social interaction and friendship, as discussed through other studies (e.g., Altback, 1991; Furnham \& Alibhai, 1985; Rienties, Johan, \& Jindal-Snape, 2015; Rienties \& Nolan, 2014; Hendrickson, Rosen, \& Aune, 2011; Hotta \& Ting-Toomey, 2013), play a significant role in supporting international students through their cross-cultural transitions and adjustment process. While some research discusses other pertinent issues of international students' experiences in the Australian context (e.g., Dalglish \& Chan, 2005; Kashima \& Pillai, 2011; Tawagi \& Mak, 2015; Yeoh, Le, \& Doan, 2013), literature that focuses on culture shock, social interaction and friendship network of international students in Melbourne is lacking. This aim of this paper is to examine these issues and to identify variables that inform and influenced international students' experience and perspectives. 


\section{Social Interaction and Friendship Development}

Social networking facilitates interaction and connections with others. Cultural modeling and dialogue are equally important in building social ties (Gill, 2007). Social capital theory has been used by other studies to investigate how students develop and maintain social relations (Heath, Fuller, \& Johnston, 2010; Lee, 2010). Social capital is linked to the value of resources in social network ties that gives better access to information to students in helping them to improve their social credentials (Rienties et al., 2015; Rienties, Tempelaar, Pinckaers, Giesbers, \& Lichel, 2010).

Research literature suggests that international students benefit from an increased contact with the host culture which improves their language skills and helps them to build their confidence to communicate (Kim, 2001; Ward et al., 2005). Friendship formation plays a significant role in how international students (Hendrickson et al., 2011) experience cross-cultural transitions and "intercultural friendship, in particular, has a lot of potentials to enhance and advance international goodwill” (Gareis, 2012, p. 310). Friendship equally contributes to how individuals satisfy deep personal and emotional needs (Hendrickson \& Rosen, 2009). Other studies (e.g., Furnham \& Alibhai, 1985; Rienties \& Nolan, 2014; Bochner, Hutnik, \& Furnham, 1985; Hendrickson et al., 2011; Kashima \& Pillai, 2011), borrowing on social capital theory and culture contact literature (Ward et al., 2005), discuss the role of 'friendship formation' towards acculturation, contentment, satisfaction, social support and success' of international students. Yet, research exploring patterns of friendship among individuals from different nationalities has been neglected (Chen, 2002).

International students form membership with several different groups (e.g., academic community, housemates, and social clubs) and they form interpersonal relationships and friendship that form their social networks (Bochner, McLeod, \& Lin, 1977; Hendrickson \& Rosen, 2009). The importance of having friends with co-nationals and host nationals is discussed by Montgomery and McDowell (2009). Similarly, maintaining social interaction with housemates and through social clubs influences international students' adjustments and increase the well-being and academic performance of international students (Rienties \& Nolan, 2014). In this paper, the focus is however on few variables that have influenced the participants' social interaction and friendship formation as they shared their personal narratives and views.

\section{RESEARCH METHOD}

The data for this paper are drawn from a study that investigated international student's experience of cross-cultural transitions experiences including culture shock, social interaction, and friendship development and the 
relevant implications on their identity, sense of belonging and agency as they adapt and adjust to their host environment. The study adopted a case study approach (Yin, 2013) and focussed on a theoretical positioning that directed the data collection and analysis process to further explore and extend understanding on the issues from the multiple perspectives of the participants (Gray,2013). In using a deductive approach, data from participants was cross-case analyzed in establishing the theoretical boundaries and the descriptive thematic approach (Gillham, 2010; Gray, 2013; Patton, 2014) to identify the common variables in the participant's responses. The construction of a data record (Trent \& Cho, 2014) or a case record as termed by Patton (2014) was useful in coding, organizing, classifying, editing and condensing data before writing the case study narratives. An inductive approach to analysis (Gray, 2013) and interpretation was used to present the multiple perspectives from the participants and these were reported as narratives of their context-specific stories and experiences. The analysis and interpretation of these narratives through the discussion in itself constitutes a narrative, which is more compelling than other interpretations.

\section{Participants}

A purposeful sampling procedure was used to sample international students who have lived and studied in Melbourne for at least two years. This study cleared ethics approval before contacting the participants, who were then invited to participate in the study through postings on social media websites. There were five male and three female students and their age range was from 20 to 40 years old. Participants were studying in different courses and universities in Melbourne. Most participants were nearing completion of their courses, while few of them were also working. Few participants had a first degree and they were in the process of finishing a Postgraduate course. There were three doctorate degree students who were awardees of scholarships and they were from different universities.

\section{Data Collection}

Interviews were used to collect data as it appropriately mapped " the woven and knotted strands of relationship” (Schostak, 2006, p. 22) of participants' shared experiences. The semi-structured interview questions encouraged participants to share their personal journey and perspectives. A broad outline of the research problem and key questions were verbally outlined to participants in addition to the plain language statement (PLS) sent prior in seeking their interest and approval to be part of the study. Voluntary consent for participation was obtained prior to interviews. The interviews were scheduled and held in a location convenient to participants and conducted in the English language. The duration of the interviews was 
at least an hour. The interviews were digitally recorded and conducted in a one-to-one individual meeting with each participant while establishing a 'balanced rapport' and a casual and friendly approach (Wilkinson \& Birmingham, 2003). The interviews were transcribed by the researcher and participants were given pseudonym names for anonymity. Coding of data involved methods for sorting and memoing of responses by categorizing applied codes and writing of memos for getting a deeper understanding in identifying the emergent themes (Saldana, 2011).

Table 1. Profile of participants

\begin{tabular}{|l|l|l|c|}
\hline $\begin{array}{l}\text { Pseudonym } \\
\text { names }\end{array}$ & Nationality & $\begin{array}{l}\text { Course completed and what } \\
\text { they are studying so far }\end{array}$ & $\begin{array}{l}\text { Number of } \\
\text { years they } \\
\text { have been in } \\
\text { Melbourne }\end{array}$ \\
\hline Han & Vietnamese & $\begin{array}{l}\text { Currently completing a Ph.D. } \\
\text { in Education }\end{array}$ & 4 years \\
\hline JMI & Indonesian & $\begin{array}{l}\text { Currently completing a Doctor } \\
\text { of Veterinary medicine }\end{array}$ & 5.5 years \\
\hline Jules & South Korean & $\begin{array}{l}\text { Completed a Bachelor of } \\
\text { Nursing }\end{array}$ & 5 years \\
\hline Ed & Mexican & $\begin{array}{l}\text { Currently completing a Ph.D. } \\
\text { in Education }\end{array}$ & 4 years \\
\hline James & Columbian & $\begin{array}{l}\text { Completed a Bachelor of Cre- } \\
\text { ative Arts in Drama. Currently } \\
\text { completing a Masters of Busi- } \\
\text { ness Administration and } \\
\text { Masters of Business and Ac- } \\
\text { counting }\end{array}$ & 5 years \\
\hline Jeremy & Chinese & $\begin{array}{l}\text { Completed a Bachelor of } \\
\text { Marketing and Finance } \\
\text { Currently completing a Mas- } \\
\text { ters of International Finance }\end{array}$ & 5 years \\
\hline Man & Indian & $\begin{array}{l}\text { Currently completing a Ph.D. } \\
\text { School of Medicine }\end{array}$ & 3 years \\
\hline Fab & Italian & $\begin{array}{l}\text { Completed a Master of teach- } \\
\text { ing }\end{array}$ & 2 years \\
\hline
\end{tabular}

Table 1. Gives a detailed profile of participants and it identifies them using pseudonym names and their nationality. It provides a description of the course the participants have completed or still studying as well the number of years they have so far lived and studied in Melbourne.

\section{Thematic Analysis of Findings}

The interpretation of findings was aimed to clarify and make meaning of the participants' shared experiences (Trent \& Cho, 2014). A narrative approach as an alternative path for interview analysis (Denzin \& 
Lincoln, 2005; Leavy, 2014), was used to discuss the findings with a particular emphasis on using verbatim quotes and excerpts from the participants' responses. The patterns and connections between different issues through the participants' responses (Denzin \& Lincoln, 2000) inform the different variables discussed in the findings. Culture shock is discussed in reference to each participant's responses related to initial experiences of cross-cultural transition in Melbourne. In discussing their experiences with social interaction and friendship development, variables including cultural similarity, intercultural communication competence, intercultural friendship and relational identity were identified as commonalities in their responses. In contextualizing the findings in the literature (Trent \& Cho, 2014), corresponding themes researched from other studies were compared (Gareis, 2012), yet the findings from this study bring a different and unique contribution to the understanding of the issues discussed.

\section{Limitations}

The absence of any triangulation of data is a limitation to this study with only interviews used as an instrument for data collection. There are various suggestions put forward to legitimize research which relates to validity and reliability and generalizability (Tobin \& Begley, 2004). Wilkinson and Birmingham (2003) asserted that interviews are the most common and powerful way to have active interactions leading to negotiated contextually based results. This inquiry focused on a particular sample of participants from different countries and cultural backgrounds and their personal accounts and shared experiences cover a multiplicity of views (Roulston, 2010) that bring coherence to the data and the discussion of findings (Fraenkel \& Wallen, 2006). The findings were re-examined through member checking as a tool for a reflexive mode of knowledge production that also established rigor and allowed triangulation of data (Cho and Trent, 2006). Participants were offered to check the coded transcripts. Defined as member validation, (Seale, 1999) this process allowed more accuracy and reduced the bias of the data while increasing the reliability of the findings.

\section{RESULTS}

\section{Culture Shock}

The participants had quite different experiences and challenges at the beginning of their stay in Melbourne. They described challenges characterized by experiences of loneliness and self-motivation as per the demand of independent living within a foreign social and academic environment while they encountered unfamiliar cultural norms both in their social and educational spheres. The cultural distance between home culture 
and the Western host culture is sometimes significant (Moores \& Popadiuk, 2011) and some participants described how familiar cues from their home country were given different meanings and interpretation within the host culture and how they had to disapprove, accept or change their beliefs. Jules described her experience as thus:

Korea is very different from his cultural background. We've got a very isolated location. We got only one ... I mean I never have seen many people from overseas. It is very monocultural, so coming over here I just tried to be open-minded. It's just the small things that bother me a lot. For example, if people are just walking on the floor with their shoes and then just lying on the bed with their shoes. It bothers me a lot because that's not part of my culture.

International students often find themselves confronted with "strangeness" in the host country (Gill, 2007, p. 171). Man and Jeremy described their experience of what they found as quite different and strange to their cultural norms from their home country. Man asserted:

Like yeah ... I found few things as a culture shock. Like one of my housemates, once like she said I have a step-mother, so in India I was like in India we don't have step-mothers - yes she was Aussie. And I mean this was one of those things. The way people speak was different.

Jeremy described his experience as such:

Yeah, like in Chinese background we normally do not stare at people - when talking to people - so eye contact is quite different and when I walk down the street - like random people say hi, how are you? To me - so which I found it was quite interesting because we Chinese we don't do that, like when you stop someone and if you talk to strangers to China it can be considered that you want something from me - yeah. Yes, it is a completely different experience.

The gap between home and host educational values was not that significant for some participants as Western assumptions might suggest (Watkins \& Biggs, 1996). Han described her experience not really as a culture shock, but more as a challenge and a change in situating herself in a new environment, although she was experiencing familiar modes of using language, teaching and learning skills and values as in her home country. 
I would not think of it as a culture shock, because before that even though I hadn't had any experience outside Vietnam, I kind of was in the field of English teaching, and I taught cultural studies and culture subjects and literature. So I have always thought of myself as a western person, rather than an Asian person in my core, but yeah, it that sense didn't see it as a culture shock, but anyway it was a big change from one environment to the another ...

James experienced more a difference in the cultural situation of approaches to teaching and learning based on his previous educational experience and skills from a different course. He had to accommodate within different sets of learning needs and expectations. James reported:

Not at all, well I have to be in the middle, because when I first came in Australia, in Melbourne, I didn't find too much of a cultural shock like I told you I had experience in other cultures in Columbia . . . Yes . . . But I still do feel . . . I don't know if it was a culture shock ... When I was in my first year in my MBA I kind of felt it, may be because it was a different course and I was in a different state of mind.

Participants had different perspectives and interpretation of 'culture shock', yet most of them experienced some kind of discomfort and disorientation within their first year of transition and adjustment. The initial adjustment was described not as difficult for some of them, however, they were challenged in putting more effort into changing their ways of living and in finding the right balance between studies, work and leisure time. Ed stated:

I wouldn't call it a culture shock in the first year in Melbourne. Not a shock as in a state of freezing yourself. It didn't freeze me but it did challenge me.

Fab responded:

No, I hmmm I don't think it could be a lot of culture shock, but it was more may be a difficult transition from being pretty much free to discipline myself to go back to be a student . . . You know to a different status, different perception of myself, different focus. . .

Cross-cultural adjustments for international students are challenging as students might need to learn and use a new language and adapt to new learning modes (Hotta \& Ting-Toomey, 2013). Gill (2007) described 
intercultural adaptation as part of the process of intercultural learning, where international students experience profound changes "transforming their understanding of learning experience, self-knowledge, awareness of other and values and worldview” (p. 167). For participants in this study, being away from their family and friends and having to live on their own made them homesick. Many of them had to reorganize their bearings and cope with emotions and thoughts as they adjusted to new ways of living. The experience of loneliness is often detrimental to international student's overall self-confidence and academic performance (Swami, Arteche, Chamorro-Premuzic, \& Furnham, 2010) and for the participants that had to re-examine their perspectives about cultural norms from home and host environment and reviewing their assumptions about belief systems and habits.

The responses from the participants outline how 'culture shock' can apply to any new situation and in renewing their perspectives they adopted other ways to adjust and reassess their beliefs to make better connections and identification (Pedersen, 1995). Participants were open and flexible to extend their views and even confront some nested stereotypes from their home culture which enabled them to look at their own culture from an outsider's standpoint. This provided them with new ways and insights to adjust in their new environment. Through their adjustment process, the participants selected more positive outcomes for personal growth and cultural learning (Hwang et al, 2016; Kim, 2001), which helped them boost their self-confidence and build a rapport with others. It also goes to show how 'culture shock' is part of the transition, adaptation, and development process, distinct to the often negative conceptualization around the early models of typology around the term in regards to cross-cultural experiences (Hwang et al, 2016; Kim, 2001; Zhou et al., 2008). 'Shock' is understood as the stimulus for the acquisition of culture-specific or behavioral social skills required to engage in new social interactions (Zhou et al., 2008). For the participants, their experience with culture shock did not really motivate them to acquire culture-specific skills for opportunities to socially engage, yet they describe other reasons that supported their decisions and choices for social connections and friendship ties.

\section{Social Interaction and Friendship Development}

Participants had rather selective motives and drives in choosing their friends and social groups. Social media gave them more opportunities to be in touch with their friends or social circles within and outside the university. Social clubs were identified as places where international students were more likely to build interaction with both host and multinational students. Different social events in connection to and outside to university were most of the time advertised through social media. Social 
media as a virtual space also provided more opportunities to connect with others and engage socially through chats and online games. Participants suggested that interaction with their peers in class was more towards group work assignments or collegial support and only rarely it could extend to friendship. There were different insights on how participants build social connectedness and friendship networks; however, the patterns and connections within their responses inform the variables discussed further.

\section{Cultural Similarity}

Cultural similarity makes behavior explanations and predictions in initial encounters easier as it builds up attributional confidence (Kim, 1991; Searle \& Ward, 1990) and it helps academic sojourners to get involved in deeper engagement and interaction. Trying to make friends with host nationals, as JMI describes, was challenging as she did not share the same cultural knowledge and background as them.

It was kind of difficult to relate to the locals, I still find it a bit difficult sometimes... because we have different experiences, we have different cultural knowledge and background. I am the only Indonesian in my VET course and others are from international backgrounds, but there are more locals. I started to be friends with the locals in my first year because I joined clubs and it is a bit hard to get a good local friend, because the way the system and the classes are structured in the first year, tutes once or twice a week; so you don't really have the time to build the connections. Also, we have different backgrounds as well, because they could talk about their childhood experiences in Australia and then. I don't have all of this. The friends that I currently have are the ones from the first year, we were in the same class we both want to get into Vet, we were in the same clubs because we have same interests like fantasy ... . and so are they still in the same group- they are in my intake and we meet each other quite frequently, so there is a lot of talking about studies? We have more regular contacts, and then we can have more things we can talk about like church.

For instance, it was hard for JMI to relate and share childhood experiences as lived by Australian friends as she felt alienated from their experiences, whereby she could not situate the "cultural uniqueness" of her own personal stories among such conversations (Kashima \& Loh, 2006) and equally the cultural similarity where she could feel at ease for 'selfdisclosure' (Morse, 1983).

Man's account of finding a landlord from his same cultural background and sharing a house with people of the same ethnicity was a 
relief and it provided him a much sorted emotional and moral support that comforted him from the sense loneliness and isolation he initially experienced on arrival in Melbourne. He was comfortable as soon as he met his co-national peers and hence he was not too motivated to bridge contact or friendship with host nationals.

When I came here like I was all alone, I didn't know anyone, I didn't have any relatives in Australia, so I didn't know anyone. So as soon as I came here I found some Indian friends in the same lab and in the same office and so, I was able to interact with them quite easily. Then I got my house owner who is also Indian...so I was able to have an Indian kind of house.

Fab had a different experience as he stayed in a shared house with Chinese students and he did not really integrate their rather closed social circle.

I had to live with people from an Asian background and probably they were quite different and they were surrounded by a more integrative network of friends, because of the bigger Chinese community and they already had friends living and studying in Melbourne, while I was pretty much the only guy from a European background.

Fab felt that cultural differences and traits were dissimilar to his own values, which made it harder to build social interaction and friendship with his housemates. His experience underlines how people from different cultural groups often have different approaches, expectations, and views to intercultural contact.

A sense of reassurance and understanding is a major factor towards social adjustment for international students (Geeraert, Demoulin, \& Demes, 2014). 'Cultural similarity' was an important factor for 'self-disclosure', and international students need the comfort and confidence to interact with others. For example, childhood memories have a 'cultural uniqueness' and there was an uneasiness in sharing such personal experiences. The concerns being unfamiliarity and lack of understanding from others. Similarly, 'cultural differences' (values and expectations that are different) create barriers to establishing friendship with individuals with distinct cultural backgrounds. For those reasons, some participants found it challenging to extend friendship to host nationals in particular. They were more comfortable with their co-national peers (i.e., housemates, classmates, or members of similar social groups) and with other international students. They thought that there was a lack of peer support for extending 
intercultural friendship outside the co-national social circle (Trice, 2007). Kim (2001) suggested that having a friendship with co-nationals hinders adaptation process in the long run and (Hendrickson et al., 2011) noted that students with more co-national friends were less satisfied with their lives. Such claims were not supported by the participants, as they felt content in their lives and over the years they have established a social network of friends including co-nationals, host nationals, and multi-nationals.

\section{Intercultural Communication Competence}

Intercultural communication competence is part of 'culture learning' and it contributes to building relationships and maintaining interpersonal involvement for international students. Participants described that the length of stay made a difference in their social life as they found cultural differences to retreat in the process of adjusting to their new environment (Gudykunst, 1985). As international students settle down they become more at ease and familiar with cultural traits of the host culture and they build understanding and re-adjustment to social expectations. Language proficiency helps to initiate and maintain communication among international students (Chen, 2002) and it enhances the scope for 'cultural immersion' (Kim, 2005). Cultural immersion as described by Kim, (2005) is generally positively related with fluency in the language of the host culture. Language was not a major issue for most of the participants as they were fluent in using English language (Rienties, Beausaert, Grohnert, Niemantsverdriet, \& Kommers, 2012). They had some difficulties in coping with the Australian accent in the beginning but somehow they were effective in communicating with others. Receptivity, ethnocentrism and even perceived discrimination (Gareis, 2012; Russell, Rosenthal, \& Thomson, 2010) are issues which can discourage international students to initiate a friendship and some of this sentiments were reported by few participants. For instance, Jules described her experience which gives some insight of her perspectives and challenges in adjusting to the host culture.

I didn't have any connection in Melbourne. My first connection started with my homestay family and then Uni and the friends here, and eventually they expanded to another group of people, kind of the toastmaster group, somehow I met my partner there. It's more about international students rather than local people or Australian people. I'm not really into the Australian culture I guess because I felt there is still a lot of communication differences/difficulties, . . . somehow I was in the International Student's group because there was just a one-year bridging course, so my classes didn't have much of Australian students, and somehow when we got half of 
International and half of Australian students in one subject, naturally they just divided, they just mingled with what they want.

\section{Intercultural Friendship}

While Jules preferred to move in a shared house where there were Korean students only, she felt more comfortable living with co-nationals that also made her more connected to her home culture. She did not deny intercultural friendship as not good for her, as she said she met her partner through a social group and he is an international student of European nationality. Jules stated:

I'm actually living in a Korean household. Only one family, I'm sharing with them. When I'm free I share my free time with them. Finding the Korean house, it's not just about culture; the most important thing to me was the cleanliness of the house. At very first I didn't mean to get to the Korean house because I wanted to improve my English and, I wanted to mingle with this society, with all different backgrounds, but I changed my mind after my first experience living in a shared house with other different nationalities. However, I try to be open to all the different cultural backgrounds.

Participants found that in some cases it was rather difficult to be part of closed social circles of either host nationals or co-nationals and this was not an encouragement towards intercultural friendship. Similarly, it is not unusual for international students to report having no host-national friends at all (Furnham \& Alibhai, 1985; Bochner et al., 1985; Gareis, 2012 ; Ward \& Masgoret, 2004) as host nationals have a well-established network of local friends ( Rienties et al., 2012; Rienties et al., 2015; Hendrickson et al., 2011). Some participants relate to similar challenges and difficulties in extending friendship with host nationals due to less mutual receptivity and their own personal choices not to do so. On the other hand, participants acknowledged that friendship was critical in supporting them in their adjustment and adaptation process. However, few of them felt more comfortable and inquisitive to learn about other cultures in sharing multinational friendship, while they shared similar experiences of challenge and struggle towards adjustment and adaptation (Hendrickson et al., 2011; Montgomery \& McDowell, 2009).

James shared his view as thus:

When I first came here it was amazing like. It was an awesome sensation because I never expected for other cultures to be like these people I met . . . very friendly. I have been in contact with many cultures: Indian culture, Chinese culture, Indonesian culture, 
Malaysian culture and I was able to get a little bit of it. So that was in the first year and that's still ongoing because I am still having many good experiences about every culture, especially with friends from the Indian origin.

Jeremy shared a similar view:

By joining different clubs I think is one of the best ways for me to interact with others. When you find some similar interests with others, so it's very easy to talk to them and that's where I found connection and like Toastmaster club and it has played a very important part role in my social interaction and networking of friends - its aims to improve your communication skills and leadership skills. Also, I think I am quite open, I have friends from all over the world and I have lots of Australian friends. I think the reason why I want to join these programs is that I want to meet some friends more to socialize with people.

Other participants talked about their friendship with multi-nationals and host nationals through their academic course or membership in social groups. For Jeremy, it improved his communication and leadership skills as he asserts such interaction helped him in building social networks, and he is positive to further extend friendship with them.

For an intercultural friendship to work, the members of a group need to be successful in negotiating their expectations and patterns of friendship (Gaines \& Liu, 2000; Pei-Wen, 2008). It is also important for international students to share similar values and beliefs in relationships and to have an understanding of each other's values and beliefs (Gaines \& Liu, 2000). A research on intercultural friendship (Krumrey-Fulks, 2001) explained that people in the Chinese culture expect friends to perform helpful behaviors, whereas American friends expect friends to be good listeners. For instance, the different perceptions and expectations towards friendship formation and what it means to be friends were pointed out by few participants. Intercultural friendship was an avenue for some of the participants to open up to others from different cultural backgrounds. James felt comfortable in his group of multi-national friends and he was keen to further his friendship with others, as he identified similar living experiences and struggles as them. Feeling emotionally secure and accepted in a group is important for international students and this builds their confidence to establish inter-cultural friendship in the host culture (Hotta \& Ting-Toomey, 2013). 


\section{Relational Identity}

From the participants' responses, there was indeed some cultural empathy in regards to how they experience intercultural contact and social ties within their academic space. Talking about his experience in interacting with his academic peers, Ed felt that it was not a language or communication issue but more the academic culture within the Ph.D. student's community which makes it difficult to make connections to go no further than a hi and hello scenario. To some extent, there was a bit of empathy emphasized with shared feelings and thoughts. Ed further shared his views as thus:

Making new friends at the beginning was hard for me because I was expecting to get all my friends at university. It didn't happen that way but I was expecting that. In Mexico, my experience was inclusive: the minute like ... who are you? Yeah . . . come on in we have a party tonight. I don't think it was because of the culture and the language or because I was feeling at home. I'm not sure of that. I'll keep thinking over that. I don't think it was language because I could communicate quite well. It might be cultural because . . . in that building you know we were people from all over the world. It would be impossible to tag, "Oh yeah Australian" . . . impossible because I'm talking about people from Indonesia, from Africa, from China . . . There was no more of this . . . the social connection among the people, it was more practical, more into the surface of, Yeah I like you, good on you, keep on working hard, see you later.

Ed also added that he made his social interaction mostly outside the university with a group of people as co-nationals who shared the same culture, language, and interests as him. Han experienced a similar situation, where it was hard for her to engage with the academic community that goes further towards friendship development. Han was more task-oriented and geared towards her studies, whilst she anchored to her home culture which suggests why she was inclined to have more co-nationals friends from Vietnam. Han said:

Oh yeah, I met some new friends, but not a lot. You know I was in a new environment, I was introduced to this faculty and I met other people who were doing their Ph.D. and I also got acquainted with the staff here although they are very busy, I don't get to meet them outside the Ph.D. supervision meetings but I know some other Ph.D. students from my first year, but they were busy too. It is the fourth year... and the pressure is building up, but it's ok! I think I am a 
private person I don't need to know a lot of people and I have meaningful relationships.

For Ed and Han being part of a mature group of independent learners, offer rather slim opportunities for friendship connections to happen and interactions remain more on a collegial stance. Their personal interests and study commitments were others factors that influenced their choices.

Relational identity is another component towards successful friendship ties and intercultural friendship (Gaines \& Liu, 2000; Pei-Wen, 2008). To have common interests, values, belief systems are factors that have a strong influence on an each other's ways of knowing, being and acting in regards to the outside world (Wood, 1982). The way to establish and maintain such factors equally influence relational identity. For some participants, they could not see social interaction to go beyond the status of membership within a particular group (for example their academic community). As a 'mini culture' (Baxter, 1987) such groups have specific protocols and established norms where members are expected to learn and interact accordingly and eventually providing lesser scope for friendship development. Ed and Han experienced more shared traits of 'cultural empathy'(Van Oudenhoven \& Van der Zee, 2002) being in similar situations. An individualistic orientation (Ting-Toomey, 1989) is another marker of selective priorities and choices to influence social dynamics (Jonasson, 2012), where individuals seek for desirable potential attributes in what can better match their interests and personality traits.

\section{CONCLUSION AND IMPLICATIONS}

There are major changes in the social and cultural landscape of global cities such as Melbourne with an increasing number of international students who eventually decide to work and live in this city after their studies. It is important to promote intercultural communication competence and intercultural friendship among international students to make them feel more confident, content and integrated within their host environment. Social interaction and friendship development play a significant role in the adjustment process of international students and in supporting their wellbeing and how they feel content and confident. Findings from the study reinforce the importance of intercultural competence and friendship for international students with both co-nationals, host nationals and multinationals as important in bridging cultural modeling and dialogue (Gill, 2007) and in improving their social credentials (Rienties et al., 2015). While this study had some limitations with a small sample of participants in Melbourne only, the findings give voice to the participant's personal stories 
and perspectives and it provides further scope and insight to extend research with a larger sample of participants in Australia.

\section{REFERENCES}

Altback, P. G. (1991). Impact and adjustment: foreign students in comparative perspective. Higher Education, 21, 305-323.

Australian Bureau of Statistics. (2012). Retrieved from http://www.abs.gov.au/AUSSTATS/abs@.nsf/Lookup/4102.0Main+Featur es20Dec+2011

Australian Education International. (2012). International Student Enrolments Data. Retrieved from https://internationaleducation.gov.au/research/International-StudentData/Pages/InternationalStudentData2012.aspx

Baxter, L. A. (1987). Symbols of relationship identity in relationship cultures. Journal of Social and Personal Relationships, 4, 261-280.

Bista, K., \& Foster, C. (2016). Global perspectives and local challenges surrounding international student mobility. Heresy, PA: IGI Global.

Bochner, S., Hutnik, N., \& Furnham, A. (1985). The friendship patterns of overseas and host students in an oxford student residence. Journal of Social Psychology, 125(6), 689.

Bochner, S., McLeod, B. M., \& Lin, A. (1977). Friendship patterns of overseas students: A functional model. International Journal of Psychology, 12(4), 277-294. doi: 10.1080/00207597708247396

Brown, J., \& Brown, L. (2013). The international student sojourn, identity conflict, and threats to well-being. British Journal of Guidance \& Counselling, 41(4), 395-413. doi: 10.1080/03069885.2012.729026

City of Melbourne. (2013). A great place to study international student strategy 2013-17. Retrieved from http://www.melbourne.vic.gov.au/AboutMelbourne/KnowledgeMelbourne/ Education/Documents/International_Student_Strategy_2013-17.pdf

Chen, L. (2002). Communication in intercultural relationships. In W. B. Gudykunst \& B. Mody (Eds.), Handbook of international and intercultural communication (2nd ed., pp. 241-258). Thousand Oaks, CA: Sage.

Cho, J., \& Trent, A. (2006). Validity in qualitative research revisited. Qualitative Research, 6(3): 319-340.

Dalglish, C. L., \& Chan, A. O. (2005). Expectations and reality- international student reflections on studying in Australia.

Denzin, N., K., \& Lincoln, Y., S., (Eds.). (2000). Handbook of qualitative research (2 Ed.). Thousand Oaks, London: Sage Publications, Inc

Denzin, N. K., \& Lincoln, Y. S. (2005). The SAGE handbook of qualitative research: Sage Publications.

Department of Education and training. (2016). Study Locations of International Students in $2015 . \quad$ Retrieved from https://internationaleducation.gov.au/research/ResearchSnapshots/Documents/Regional\%20study\%20locations_FINAL.pdf 
East, J. (2001). International Students Identified as Customers: Their Expectations and Perceptions. Changing Identities.

Edwards, D. (2011). International Students Snapshot: A Global Picture, Joining the Dots Research Briefings; 1, 2202-1779. http://research.acer.edu.au/joining_the_dots/21

Fraenkel, J. R., \& Wallen, N. E. (2006). How to Design and Evaluate Research in Education (6 Ed.). Boston: Mc Graw Hill.

Furnham, A., \& Alibhai, N. (1985). The Friendship Networks of Foreign Students: A Replication and Extension of the Functional Model. International Journal of Psychology, 20(3/4), 709-722. doi: 10.1080/00207598508247565

Furnham, A., \& Bochner, S. (1986). Culture Shock: Psychological Reactions to Unfamiliar Environments: Methuen.

Gaines, S. O., \& Liu, J. H. (2000). Multicultural/Multiracial Relationships. In C. Hendrick \& S. S. Hendrick (Eds.), Close Relationships (pp. 97-110). Thousand Oaks. CA: Sage.

Gareis, E. (2012). Intercultural Friendship: Effects of Home and Host Region. Journal of International and Intercultural Communication, 5(4), 309-328. doi: 10.1080/17513057.2012.691525

Geeraert, N., Demoulin, S., \& Demes, K. A. (2014). Choose your (International) Contacts Wisely: A Multilevel Analysis on the Impact of Intergroup Contact while Living Abroad. International Journal of Intercultural Relations, 38, 86-96. doi: http://dx.doi.org/10.1016/j.ijintrel.2013.08.001

Gill, S. (2007). Overseas Students' Intercultural Adaptation as Intercultural Learning: A Transformative Framework. Compare: A Journal of Comparative and International Education, 37(2), 167-183. doi: 10.1080/03057920601165512

Gillham, B. (2010). Case Study Research Methods: Bloomsbury Publishing. Gray, D. E. (2013). Doing Research in the Real World: SAGE Publications.

Gu, Q., Schweisfurth, M., \& Day, C. (2010). Learning and Growing in a 'Foreign' Context: Intercultural Experiences of International Students. Compare: A Journal of Comparative and International Education, 40(1), 7-23. doi: 10.1080/03057920903115983

Gudykunst, W. B. (1985). A Model of Uncertainty Reduction in Intercultural Encounters. Journal of Language and Social Psychology, 4(2), 79-98. doi: 10.1177/0261927x8500400201

Heath, S., Fuller, A., \& Johnston, B. (2010). Young people, Social Capital and Network-Based Educational Decision-Making. British Journal of Sociology of Education, 31(4), 395-411. doi: 10.1080/01425692.2010.484918

Hendrickson, B., \& Rosen, D. (2009). Intercultural Networking: An Analysis of International Students' Friendship Networks and Satisfaction. Conference Papers -- International Communication Association, 1-35.

Hendrickson, B., Rosen, D., \& Aune, R. K. (2011). An Analysis of Friendship Networks, Social Connectedness, Homesickness, and Satisfaction Levels of International Students. International Journal of Intercultural Relations, 35(3), 281-295. doi: 10.1016/j.ijintrel.2010.08.001 
Hotta, J., \& Ting-Toomey, S. (2013). Intercultural Adjustment and Friendship Dialectics in International Students: A Qualitative Study. International Journal of Intercultural Relations, 37(5), 550-566. doi: 10.1016/j.ijintrel.2013.06.007

Hwang, E., Martirosyan, N., M., \& Moore, G. W. (2016). A review of literature on adjustment issues of international students: Recommendations for future practices and research. In K. Bista \& C. Foster (Ed.), Global perspectives and local challenges surrounding international student mobility. Hearsay, PA: IGI Global.

Jonasson, C. (2012). Teachers and Students' Divergent Perceptions of Student Engagement: Recognition of School or Workplace Goals. British Journal of Sociology of Education, 33(5), 723-741. doi: $10.1080 / 01425692.2012 .674811$

Kashima, E. S., \& Loh, E. (2006). International Students’ Acculturation: Effects of International, Conational, and Local Ties and Need for Closure. International Journal of Intercultural Relations, 30(4), 471-485. doi: http://dx.doi.org/10.1016/j.ijintrel.2005.12.003

Kashima, E. S., \& Pillai, D. (2011). Identity Development in Cultural Transition: The Role of Need for Closure. Journal of Cross-Cultural Psychology, 42(5), 725-739 715p. doi: 10.1177/0022022110362749

Kim, Y. Y. (2001). Becoming Intercultural: An Integrative Theory of Communication and Cross-Cultural Adaptation: SAGE Publications.

Kim, Y. Y. (1991). Intercultural Communication Competence: A Systems-Theoretic View. In S. Ting-Toomey \& F. Korzenny (Eds.), Cross-cultural Interpersonal Communication (pp. 259-275). Newbury Park, CA: Sage.

Kim, Y. Y. (2005). Inquiry in Intercultural and Development Communication. Journal of Communication, 55(3), 554-577. doi: 10.1111/j.14602466.2005.tb02685.x

Krumrey-Fulks, K. S. (2001). At the Margins of Culture: Intercultural Friendship between Americans and Chinese in an Academic Setting. (Unpublished doctoral dissertation), University of Kentucky, Lexington, KY

Leavy, P. (2014). The Oxford Handbook of Qualitative Research: Oxford University Press.

Lee, M. (2010). Researching Social Capital in Education: Some Conceptual Considerations Relating to the Contribution of Network Analysis. British Journal of Sociology of Education, 31(6), 779-792. doi: 10.1080/01425692.2010.515111

Mansouri, F. (Ed.). (2009). Youth Identity and Migration. Australia: Common Ground Publishing Ltd.

Marginson, S. (2011). Global context of Education and the Role of International Education in Australia, Paper presented at the AEI-supported International Education Research-Policy Symposium, Melbourne, April.

Montgomery, C., \& McDowell, L. (2009). Social Networks and the International Student Experience: An International Community of Practice? Journal of Studies in International Education, 13(4), 455-466. doi: $10.1177 / 1028315308321994$ 
Moores, L., \& Popadiuk, N. (2011). Positive Aspects of International Student Transitions: A Qualitative Inquiry. Journal of College Student Development, 52(3), 291-306.

Morse, S. J. (1983). Requirements for Love and Friendship in Australia and Brazil. Australian Journal of Psychology, 35, 469-476.

Murray, D., Hall, R., Leask, B., Marginson, S., \& Ziguras, C. (2011). Background Paper, State of Current Research in International Education. Paper presented at the AEI supported International Education Research-Policy Symposium, 8 April 2011, Melbourne.

Oberg, K. (1960). Culture Shock: Adjustment to New Cultural Environments', Practical Anthropology (7), 177-182.

Patton, M. Q. (2014). Qualitative Research \& Evaluation Methods: Integrating Theory and Practice: SAGE Publications.

Pedersen, P. (1995). The Five Stages of Culture Shock: Critical Incidents around the World: Greenwood Press.

Pei-Wen, L. (2008). Stages and Transitions of Relational Identity Formation in Intercultural Friendship: Implications for Identity Management Theory. Journal of International \& Intercultural Communication, 1(1), 51-69. doi: $10.1080 / 17513050701690918$

Pham, L., \& Saltmarsh, D. (2013). International Students' Identities in a Globalized World: Narratives from Vietnam. Journal of Research in International Education, 12(2), 129-141. doi: 10.1177/1475240913481171

Pyvis, D., \& Chapman, A. (2005). Culture Shock and the International Student 'Offshore'. Journal of Research in International Education, 4(1), 23-42 20p.

Rienties, B., Beausaert, S., Grohnert, T., Niemantsverdriet, S., \& Kommers, P. (2012). Understanding Academic Performance of International Students: The Role of Ethnicity, Academic, and Social Integration. Higher Education, 63(6), 685-700.

Rienties, B., Johan, N., \& Jindal-Snape, D. (2015). A Dynamic Analysis of Social Capital-Building of International and UK students. British Journal of Sociology of Education, 36(8), 1212-1235. doi: 10.1080/01425692.2014.886941

Rienties, B., \& Nolan, E.-M. (2014). Understanding Friendship and Learning Networks of International and Host students using Longitudinal Social Network Analysis. International Journal of Intercultural Relations, 41, 165180. doi: 10.1016/j.ijintrel.2013.12.003

Rienties, B., Tempelaar, D., Pinckaers, M., Giesbers, B., \& Lichel, L. (2010). The Diverging Effects of Social Network Sites on Receiving Job Information for Students and Professionals. International Journal of Sociotechnology and Knowledge Development (IJSKD), 2(4), 39-53. doi: 10.4018/jskd.2010100103

Roulston, K. (2010). Reflective Interviewing: A Guide to Theory and Practice: SAGE Publications.

Russell, J., Rosenthal, D., \& Thomson, G. (2010). The International Student Experience: Three Styles of Adaptation. Higher Education, 60(2), 235-249. doi: 10.1007/s10734-009-9297-7

Saldana, J. (2011). Fundamentals of Qualitative Research: Oxford University Press. 
Schostak, J. (2006). Interviewing and Representation in Qualitative Research. New York: Open University Press.

Seale, C. (1999). Guiding Ideals: In Introducing Qualitative Methods: The Quality of Qualitative Research (pp. 32-50). SAGE Publications. doi: 10.4135/9780857020093.n4

Searle, W., \& Ward, C. (1990). The Prediction of Psychological and Sociocultural Adjustment during Cross-Cultural Transitions. International Journal of Intercultural Relations, 14(4), 449-464. doi: http://dx.doi.org/10.1016/0147-1767(90)90030-Z

Swami, V., Arteche, A., Chamorro-Premuzic, T., \& Furnham, A. (2010). Sociocultural Adjustment among Sojourning Malaysian Students in Britain: A Replication and Path Analytic Extension. Soc Psychiatry Psychiatr Epidemiol, 45(1), 57-65. doi: 10.1007/s00127-009-0042-4

Tawagi, A. L., \& Mak, A. S. (2015). Cultural Inclusiveness Contributing to International Students' Intercultural Attitudes: Mediating Role of Intergroup Contact Variables. Journal of Community \& Applied Social Psychology, 25(4), 340-354. doi: 10.1002/casp.2218

Ting-Toomey, S. (1989). Identity and Interpersonal Bonding. In Asante MK. \& Gudykunst WB. (Eds.), Handbook of International and Intercultural Communication (pp. 351-373). Newbury Park: CA: Sage.

Tobin, G. A., \& Begley, C. M. (2004). Methodological Rigour within Qualitative Framework. Journal of Advanced Nursing, 48(4), 388-396.

Trent, A., \& Cho, J. (2014). Interpretation Strategies: Appropriate Concepts in P. Leavy (Ed.), The Oxford Handbook of Qualitative Research. Oxford New York Oxford University Press.

Trice, A. G. (2007). Faculty Perspectives Regarding Graduate International Students' Isolation from Host National Students. International Education Journal, 8(1), 108-117.

Van Oudenhoven, J. P., \& Van der Zee, K. I. (2002). Predicting Multicultural Effectiveness of International Students: The Multicultural Personality Questionnaire. International Journal of Intercultural Relations, 26(6), 679694. doi: http://dx.doi.org/10.1016/S0147-1767(02)00041-X

Ward, C., Bochner, S., \& Furnham, A. (2005). The Psychology of Culture Shock: Taylor \& Francis.

Ward, C., \& Masgoret, A. M., (2004). (2004). The Experiences of International Students in New Zealand: Report on the Results of the National Survey.

Watkins, D., \& Biggs, J. (1996). The Chinese Learner: Cultural, Psychological and Contextual Influences, Hong Kong and Melbourne.

Wilkinson, D., \& Birmingham, P. (2003). Using Research Instruments: A Guide for Researchers. London and New York: Routledge Falmer.

Wood, J. T. (1982). Communication and Relational Culture: Bases for the Study of Human Relationships. Communication Quarterly, 30, 75-84.

Yeoh, J. S. W., Le, T., \& Doan, T. (2013). The Challenges of International Research Students Studying in an Australian University Context. Paper presented at the International Conference: Innovative Research in a Changing and Challenging World.

Yin, R. K. (2013). Case Study Research: Design and Methods: Thousand Oaks CA: SAGE Publications. 
Zhou, Y., Jindal-Snape, D., Topping, K., \& Todman, J. (2008). Theoretical Models of Culture Shock and Adaptation in International Students in Higher Education. Studies in Higher Education, 33(1), 63-75. doi: $10.1080 / 03075070701$

NISH BELFORD, Ph.D., is a Lecturer in Education. Her research interests include identity politics in diverse and transnational spaces and discourses around cultural transitions, culture shock and acculturation. Email: nish.belford@monash.edu

Manuscript submitted: June 27, 2016

Manuscript revised: October17, 2016

Accepted for publication: October 28, 2016

$* * *$ 